\title{
Dynamic Expression and Regulation of Urotensin I and Corticotropin-Releasing Hormone Receptors in Ovary of Olive Flounder Paralichthys olivaceus
}

\author{
Hong Zhou ${ }^{1,2 t}$, Chunmei Ge ${ }^{1,2 t}$, Aqin Chen ${ }^{1,2 *}$ and Weiqun Lu ${ }^{1,2,3 *}$ \\ ${ }^{1}$ National Demonstration Center for Experimental Fisheries Science Education, Shanghai Ocean University, Shanghai, China, \\ ${ }^{2}$ Key Laboratory of Exploration and Utilization of Aquatic Genetic Resources, Ministry of Education, Shanghai Ocean \\ University, Shanghai, China, ${ }^{3}$ International Research Center for Marine Biosciences at Shanghai Ocean University, Ministry \\ of Science and Technology, Shanghai, China
}

OPEN ACCESS

Edited by:

Pung P. Hwang,

Academia Sinica, Taiwan

Reviewed by:

Shinya Shikina,

National Taiwan Ocean University,

Taiwan

Deshou Wang

Southwest University, China

*Correspondence:

Aqin Chen

aqchen@shou.edu.cn

Weiqun Lu

wqlv@shou.edu.cn

${ }^{\dagger}$ These authors have contributed equally to this work

Specialty section: This article was submitted to

Aquatic Physiology,

a section of the journal

Frontiers in Physiology

Received: 13 May 2019

Accepted: 30 July 2019

Published: 13 August 2019

Citation:

Zhou H, Ge C, Chen A and Lu W (2019) Dynamic Expression

and Regulation of Urotensin I and Corticotropin-Releasing Hormone Receptors in Ovary of Olive Flounder

Paralichthys olivaceus.

Front. Physiol. 10:1045.

doi: 10.3389/fphys.2019.01045
Urotensin I ( $\mathrm{UI})$, a fish corticotropin-releasing hormone $(\mathrm{CRH})$ like peptide, has been found throughout vertebrate species that has great effects on adaptive physiology comprising stress-related responses, and osmotic regulation by binding with $\mathrm{CRH}$ type I receptor (CRHR1) and $\mathrm{CRH}$ type || receptor (CRHR2) in fish. Dynamic expression and regulation of $\mathrm{UI}$ and $\mathrm{CRH}$ receptors in the olive flounder ovarian follicle were studied so as to make further efforts to understand the role of $\mathrm{UI}$ in the development of teleost ovary. The results showed that stage-specific change in UI mRNA levels in ovarian follicles of olive flounder. UI and CRHR1 mRNA levels were higher in stage III follicles (300 500 $\mu \mathrm{m}$ diameter) compared to stage II (90 300 $\mu \mathrm{m}$ diameter) and IV (500 800 $\mu \mathrm{m}$ diameter) follicles, however, the levels of CRHR2 mRNA were decreased in line with the ovarian development from stage II to stage IV. A strong signal of UI protein was observed in the follicular cells and oocyte in stage III and IV follicles by immunohistochemistry. In vitro treatment of olive flounder ovarian follicles with human chorionic gonadotropin $(\mathrm{hCG})$ showed that the mRNA expression of $\mathrm{UI}$ increased significantly at low concentration and decreased at high concentration at $6 \mathrm{~h}$, but the CRHR1 and CRHR2 mRNA did not change obviously. In addition, the results of incubation with $17 \alpha, 20 \beta$-dihydroxy-4oregnen-3-one (DHP) show that UI and CRHR1 mRNA expression were elevated with increasing concentrations at $9 \mathrm{~h}$. All above results indicated that $\mathrm{UI}$ and $\mathrm{CRH}$ receptors may have a vital effect on olive flounder ovarian development.

Keywords: Urotensin I, corticotropin-releasing hormone receptors, Paralichthys olivaceus, folliculogenesis, ovarian development

\section{INTRODUCTION}

Urotensin I (UI) was comprised of 41 -amino acid belongs to the superfamily of $\mathrm{CRH}$, which also includes the mammalian UI ortholog, urocortin I (Ucn I) (Lederis et al., 1982; Lovejoy and Balment, 1999; Lu et al., 2004). It was first isolated from the urophysis of the white sucker Catostomus commersoni in 1982 (Lederis et al., 1982). Urocortins play a significant role in many crucial 
functions such as cardiovascular homeostasis, suppression of orexis, and synthesis of glucocorticoid in mammals (Vaughan et al., 1995; Ames et al., 1999; Pittman and Hollenberg, 2009). It also has been demonstrated to be directly participated in regulating steroid production in the ovary (Muramatsu et al., 2001; Florio et al., 2004; Oki and Sasano, 2004; Wypior et al., 2011). Injection of UI irritates pituitary cells of coho salmon Oncorhynchus kisutch secreting thyroid-stimulating hormone in vitro (Larsen et al., 1998); it also inhibits ingestion and add plasma cortisol content in a dose-dependent pattern in goldfish Carassius auratus (Fryer et al., 1983; Bernier, 2006). Moreover, UI plays an important role in adaptive physiology comprising stress-related responses and osmotic regulation in fish (Craig et al., 2005).

It was found that Ucn I mRNA exists not only in the cerebellum and cerebral cortex but also in the pons and hypothalamus of human brain (Takahashi et al., 1998). In human ovary, Ucn I was discovered in intrathecal cells of dominant/nondominant follicles (including follicles and luteal phase) and atresia follicles (Muramatsu et al., 2001). Ucn I mRNA was not only strongly found in the Edinger-Westphal nucleus (EWN) and olivary nucleus in the rat brain but also found in the front and middle portion of the pituitary (Bittencourt et al., 1999). The expression of UI mRNA was basically detected in cerebellum, hypothalamus, telencephalon/preoptic area, medulla oblongata, and optic tectum/thalamus. Whereas, it was not discovered in pituitary and olfactory bulb in goldfish brain (Bernier et al., 1999). However, the levels UI mRNA was discovered in the nucleus of outboard tuberis and preoptic area (Morley et al., 1991). Even though UI exist in given brain areas in both fish and mammals, a primary origin of UI in the circulation of fish was considered to be the caudal neurosecretory system (CNSS) (Lu et al., 2004). UI mRNA was primarily detected in the urophysis of carp and rainbow trout instead of in the brain, implying that UI has a relatively large effect on peripheral tissues compared with the brain (Lovejoy, 2009). However, the changes of UI in ovarian development has not been explored so far in fish. It was still required further research to demonstrate if UI has a physiological effect on the regulation of reproduction or not.

Since urocortin was one of members of the CRH family, it combines $\mathrm{CRH}$ receptors subtypes, CRH type I receptor (CRHR1) and CRH type II receptor (CRHR2), for action on stress-related responses, and reproduction (Makrigiannakis et al., 2018). In mammals, the CRH receptors have been found in the female reproductive system and taken part in domination of the hypothalamic-pituitary-ovarian axis (Makrigiannakis et al., 2018). In fishes, two type of CRH receptors, CRHR1 and CRHR2, have also been cloned and characterized (Arai et al., 2001; Pohl et al., 2001). Furthermore, the high mRNA expression of CRHR1 and CRHR2 have been observed in the ovary of African cichlid fish Astatotilapia burtoni and Japanese pufferfish Fugu rubripes (Cardoso et al., 2003; Chen and Fernald, 2008). In salmon, CRHR1 was discovered in the ovary, heart, skeletal muscle, gill and brain, but CRHR2 was only found in brain and heart by RTPCR (Pohl et al., 2001). The demonstration of combined research in chum salmon Oncorhynchus keta and catfish Silurus asotus indicates that CRHR1 and CRHR2 cannot distinguish CRH and UI (Singh and Rai, 2011). It is still ambiguous whether CRH peptides regulate the ovary development and oocyte maturation by activating $\mathrm{CRH}$ receptors.

Previous studies have demonstrated that the expression levels of UI mRNA showed a significant seasonal alteration, meanwhile, the gonadal index (GSI) in April was higher than August to October ( $\mathrm{Lu}$ et al., 2007; Westring et al., 2008). Moreover, UI from the brain has been shown to play a role in the regulation of cortisol levels in spawning Cherry Salmon Oncorhynchus masou (Westring et al., 2008). In present study, our objective was to determine whether UI and $\mathrm{CRH}$ receptors are expressed in the olive flounder ovary during ovarian development, and regulated by human chorionic

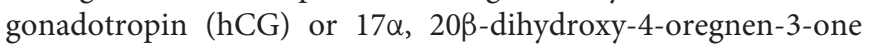
(DHP). Therefore, we analyzed temporal expression patterns of $\mathrm{UI}$ and CRH receptors in olive flounder ovary in the time of the sexual maturity and their stage-dependent in isolated budding follicles. Meanwhile, the localization of UI in olive flounder ovary was detected by immunohistochemistry. In addition, using in vitro experiment, we also investigated whether UI and CRH receptors expression were affected by hCG and DHP in olive flounder.

\section{MATERIALS AND METHODS}

\section{Animals}

Gynogenetic olive flounders were raised in recirculating aquaculture system of seawater $(30 \% 0)$ at the Central Experimental Station of Chinese Academy of Fisheries Sciences (Beidaihe, Hebei, China) (Liu et al., 2012). The test was carried out at the same site in April 2018. A total of 6 gynogenetic olive flounders (weight: 2,000 $\pm 200 \mathrm{~g}$ ) were casually assorted in 3 tanks where there was flow-through, filtered seawater (30\%0) system at $20 \pm 1^{\circ} \mathrm{C}$ over 2 weeks. Each water tank was surrounded by black plastic light-proof curtains, and was equipped with white fluorescent lamps for artificial lighting. The average light intensity was about 40 lux, which was measured at the bottom of each tank. In order to reduce the influence of feeding, fish were starved throughout the experiment. The experimental protocol was approved by the Institutional Animal Care and Use Committee (IACUC) of Shanghai Ocean University (SHOU), Shanghai, China, and abides by the Guidelines on Ethical Treatment of Experimental Animals established by the Ministry of Science and Technology, China.

\section{Isolation and Incubation of Olive Flounder Follicles}

The six flounders were anesthetized with tricaine methanesulfonate $(200 \mathrm{mg} / \mathrm{L})$ and decapitated before anatomy. The ovaries were then dissected and weighed to analyze gonad-somatic index (GSI) $[$ GSI = gonad weight(g)/total body weight $(\mathrm{g}) \times 100$ ]. One part of gonad samples was fixed and used to determine the developmental stage by histological and immunohistochemical analysis (Radonic and Macchi, 2009; Ding et al., 2013). The other part of gonad samples was 
frozen in liquid nitrogen at once for subsequent analysis of genetic expression.

The ovaries were put in a $100-\mathrm{mm}$ culture dish which contains 60\% Leibovitz L-15 (Gibco, Carlsbad, CA, United States) medium. Ovarian follicles were carefully severed with the help of fine forceps and blades. The follicles were measured by ophthalmic micrometer under an anatomical microscope. The healthy follicles at different developmental stages were grouped according to the reference follicles diameter (Radonic and Macchi, 2009; Ding et al., 2013): stage II 90 300 $\mu \mathrm{m}$, stage III $300 \sim 500 \mu \mathrm{m}$, and stage IV 500 800 $\mu \mathrm{m}$. Stage IV follicles with normal shape and clear boundary were chosen and incubated in 24-well culture plates (50 follicles/well) with $60 \% \mathrm{~L}-15$. The culture plates were incubated at $16^{\circ} \mathrm{C}$ in an incubator for treatment experiment of recombinant hCG $(0,10,20$, and $50 \mathrm{IU})$ (Sigma-Aldrich, United States) for 3, 6, and $9 \mathrm{~h}$ or DHP (0, 10, 100, and $1000 \mathrm{ng} / \mathrm{ml}$ ) (Sigma-Aldrich, United States) for $9 \mathrm{~h}$, respectively. There are six replicates for each hCG or DHP concentration treatment. After incubation, the samples were collected and directly frozen in liquid nitrogen for succeeding analysis of genetic expression.

\section{Quantitative Real-Time RT-PCR (qPCR)}

Total RNA was extracted from ovaries and follicles at different stages by RNAiso Plus (TaKaRa, Japan) as recommended by the manufacturer. The purity and integrity of RNA was analyzed by Nano Drop ND-1000 spectrophotometer (Nanodrop Technologies Inc., Wilmington, DE, United States) and 1\% agarose gel, respectively. $1 \mu \mathrm{g}$ total RNA was treated by PrimeScript ${ }^{\mathrm{TM}}$ RT reagent kit (Takara, Dalian, China). qPCR was performed using SYBR Premix Ex Taq ${ }^{\mathrm{TM}}$ (TaKaRa, Dalian, China) in an ABI 7500 (Applied Biosystems, Carlsbad, CA, United States). Relative quantification of the target gene transcripts was analyzed using $\beta$-actin gene expression as the reference gene. Following were the conditions for qPCR: $2 \mathrm{~min}$ at $50^{\circ} \mathrm{C}, 10 \mathrm{~min}$ at $95^{\circ} \mathrm{C}$ and then 40 cycles of the following process of $15 \mathrm{~s}$ at $95^{\circ} \mathrm{C}$ and $30 \mathrm{~s}$ at $60^{\circ} \mathrm{C}$. The primers were designed using Primer Premier 6 software (PREMIER Biosoft International, Palo Alto, CA, United States) and synthesized commercially (Sangon Biotech, Shanghai, China) (Table 1). To determine the specificity of the amplification, the melting curve analysis of the PCR products was performed to ensure that only one fragment was amplified. The $2^{-\Delta \Delta \mathrm{Ct}}$ method was utilized to analyze the real-time PCR data (Livak and Schmittgen, 2001).

TABLE 1 | Primer sequences used for real-time PCR amplifications.

\begin{tabular}{lll}
\hline Gene & Primers $\left(\mathbf{5}^{\prime} \mathbf{-} \mathbf{3}^{\prime}\right)$ & GenBank \\
\hline UI & F: GACCTGCTGAGCGACAAC & XM_020105024.1 \\
RRHR1 & R: TCATCCTCGGCTATCTGG & \\
& R: ACCTCATCACCGCCTTCATCC & XM_020113112.1 \\
CRHR2 & F: TGGCACCGTTGGCAGGACAA & XM_020102084.1 \\
\multirow{3}{*}{-actin } & R: CGGAGGCTGCGAGGAGATTACA & \\
& F: GGAATCGTGCGTGACATTAAG & HQ386788.1 \\
& R: CCTCTGGACAACGGACCTCT &
\end{tabular}

\section{Immunohistochemistry}

Paraformaldehyde-fixed ovary were dehydrated in ethanol, cleared in xylene and embedded in paraplast. Every section (10$\mu \mathrm{m}$-thick) was cut on a microtome (Leica, Germany) and $10 \mu \mathrm{m}$ paraffin sections were stained using hematoxylin and eosin to observe the follicle cells at different stages. Briefly, tissue sections were dewaxed in xylene and rehydrated in gradient alcohol. Endogenous peroxidase activity was blocked with $3 \% \mathrm{H}_{2} \mathrm{O}_{2}$ in methanol before slides were placed in $0.01 \mathrm{M}$ citrate buffer and heated in a water bath for $20 \mathrm{~min}$ at $95^{\circ} \mathrm{C}$. After cooling, sections were rinsed in PBS. For UI immunohistochemistry, sections were treated with fetal bovine serum (FBS) blocking solution (1\% blocking, dissolved in MABT, and 5\% FBS in PBST, PBS with $0.1 \%$ Triton X-100) for $1 \mathrm{~h}$ at room temperature (RT) to reduce non-specific staining and incubated with 1:500 rabbit anti-UI antibody (Lu et al., 2004) diluted with PBS in a moist chamber at $4^{\circ} \mathrm{C}$ overnight. The moist chamber was transferred into an air oven at $37^{\circ} \mathrm{C}$ for $45 \mathrm{~min}$, then washed six times at RT in PBST for 15 min each time at RT and 1:500 goat anti-rabbit I gG $(\mathrm{H}+\mathrm{L})$ highly cross adsorbed secondary antibody (Thermo Fisher Scientific, United States), diluted with PBS for $1 \mathrm{~h}$ in dark. Finally, the sections were stained with the DAB staining kit (Boster, China). The negative control group was incubated with PBS instead of the primary antibody to verify the specificity of immunostaining.

\section{Statistical Analysis}

SPSS 25.0 software package was used for all statistical analyses. For statistical analysis, the expression levels of target genes were standardized to that of the internal control $\beta$-actin and expressed as fold change relative to the control group. Statistical differences were detected using one-way ANOVA, and LSD post-mortem analysis was then performed to assess the differences between specific groups. The effects of time, concentration, and their interactions were analyzed using a two-way ANOVA. All the results were expressed by mean \pm SEM, and the difference was statistically significant $(p<0.05)$.

\section{RESULTS}

\section{Determination of Ovarian Development Stage}

The GSI of olive flounders at ovarian stage II, III and IV were increased progressively at $1.54 \pm 0.31,6.03 \pm 4.04$, and $9.4 \pm 2.85$, respectively. At the stage III and stage IV ovaries were become mature as vitellogenic follicle of 300-500 $\mu \mathrm{m}$ in diameter and postvitellogenic follicle of $500-800 \mu \mathrm{m}$ in diameter, respectively. There were some small yolk granules in the mazarine cytoplasm (stage II follicle). The germinal vesicle (GV) was found in the central position and many large lipid droplets and cortical alveoli were dispersed in the cytoplasm (stage III follicle). As the number and size of yolk granules increased, it almost completely occupies the entire cytoplasm (stage IV follicle) (Figures 1A-C). The results of morphology and histology indicate that the ovarian development of olive flounder was asynchronous, and oocytes of 


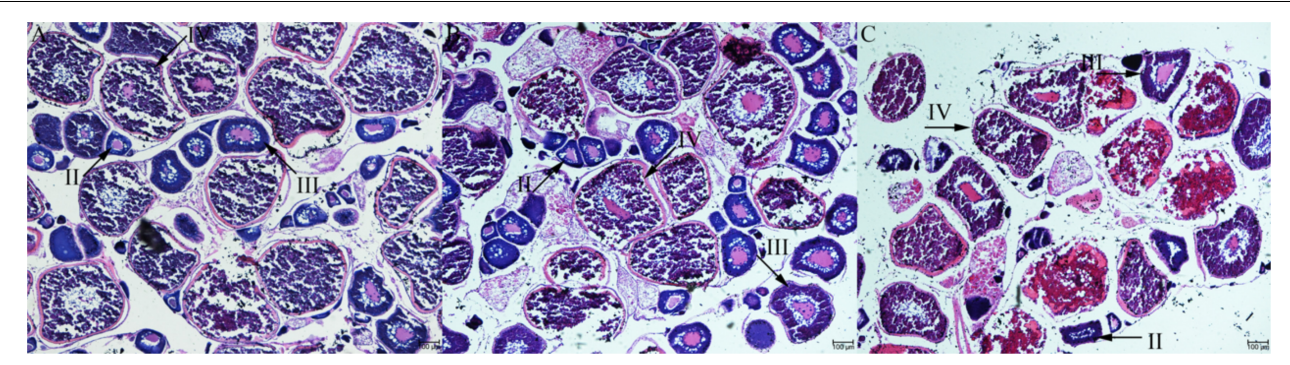

FIGURE 1 | Histological section of Japanese flounder ovaries at different stages of follicle development. stage II (A), stage III (B), and stage IV (C). Scale bar $=100 \mu \mathrm{m}$.

different development stages can be simultaneously found in the same ovary (Figure 1).

\section{Expression of UI and CRH Receptors at the Ovary Level During Ovarian Development}

The expression level of UI and CRHR1 mRNA was the highest in stage III and moderately decreased at stage IV without significant difference (Figures 2A,B). By comparison, the expression of CRHR2 mRNA levels was gradually decreased in line with the ovarian development, with the lowest in stages IV (Figure 2C). Meanwhile, the expression of the $\mathrm{CRH}$ receptors was much higher than that of UI gene during ovarian development.

\section{Stage-Dependent Expression of UI and CRH Receptors at the Follicle Level}

We performed experiments to detect the mRNA expression of UI and CRH receptors in stage II, III, and IV follicles for purpose of determining whether there is follicular dependence on mRNA expression of $\mathrm{UI}$ and $\mathrm{CRH}$ receptors. The expression of UI mRNA level in the stage II follicle was lower than that at the stage III follicle, increased apparently to the highest level at follicle of stage III, and then sharply decreased at stage IV follicle (Figure 3A). There was no significant difference in CRHR1 mRNA levels between the three stages of follicles (Figure 3B). The CRHR2 mRNA levels in stage IV follicles were sharply depressed compared to stage II and stage III follicle, showing a significant statistical difference (Figure 3C) $(P<0.05)$.

\section{Immunohistochemistry Localization of UI in the Ovarian Follicle}

The localization of UI protein in olive flounder ovary was detected by immunohistochemistry. Immunoreactivity of UI was located at follicles and dynamic change existed in different stage follicles. Immunoreactivity of UI were detected in the stage III and stage IV oocytes and follicular cells of the ovarian follicles (Figure 4). There was no positive signal in stage II follicles (Figure 4B). In stage III follicles, immunoreactive UI was detected in cytoplasm and not found in nuclei of oocyte (Figures 4C,D). Immunoreactivity of UI was present in the follicular cells, cytoplasm and the nuclei of oocyte at the stage IV follicles (Figures 4E,F). As follicular development and vitellogenesis progress, the positive signal of UI became stronger. There was no positive signal in the negative control group sections, in which the primary antibody was replaced with PBS buffer (Figure 4A).

\section{Effect of hCG on the Expression of UI and CRH Receptors mRNA}

In order to determine the effect of gonadotropins on UI and $\mathrm{CRH}$ receptors, the variation of UI and CRHR mRNA levels were detected in stage IV follicle by the hCG treatment in vitro. CRHR2 mRNA expression was markedly influenced by concentration, time and reciprocity of concentrations and time (Table 2). After three different concentration of hCG treatment, the mRNA expression of flounder UI and CRHR1 were mildly increased with no noteworthy difference compared with control group at $3 \mathrm{~h}$ (Figures 5A,B), but the CRHR2 mRNA levels were decreased significantly (Figure 5C). After 6 h, UI gene expression immediately increased at $10 \mathrm{IU} / \mathrm{ml}$, reaching the highest value at $20 \mathrm{IU} / \mathrm{ml}$. At $50 \mathrm{IU} / \mathrm{ml}$, the UI mRNA value dropped to a lower level compared to the control group. A similar trend occurred at $9 \mathrm{~h}$, but the difference is that the expression of $\mathrm{UI}$ remains high at $50 \mathrm{IU} / \mathrm{ml}$ (Figure 5A). After three different concentrations of hCG treatment, CRHR1 expression increased slightly compared with control group at 6 and $9 \mathrm{~h}$, but this did not reach statistical significance (Figure 5B). After $6 \mathrm{~h}$, the expression of CRHR2 mRNA was slightly decreased at $10 \mathrm{IU} / \mathrm{ml}$, reaching the lowest value at $20 \mathrm{IU} / \mathrm{ml}$ and then returned to normal level at $50 \mathrm{IU} / \mathrm{ml}$. Interestingly, this trend is contrary to the expression of the UI. The expression of CRHR2 mRNA was slightly increased at $10 \mathrm{IU} / \mathrm{ml}$, and reached the highest level at $50 \mathrm{IU} / \mathrm{ml}$ after $9 \mathrm{~h}$. Moreover, the level of CRHR2 between control group and $50 \mathrm{IU} / \mathrm{ml}$ exists remarkable differences $(P<0.05)$ (Figure 5C).

\section{Effect of DHP on the Expression of UI and CRH Receptors mRNA}

UI gene expression immediately increased at $10 \mathrm{ng} / \mathrm{ml}$, reaching the highest value at $100 \mathrm{ng} / \mathrm{ml}$. At $1000 \mathrm{ng} / \mathrm{g}$, the UI value dropped to a higher level compared to the control group. But, there was no significant difference on UI level after $9 \mathrm{~h}$ DHP treatment (Figure 6A). Similarly, after three different concentration of DHP treatment, flounder CRHR1 expression was gradually elevated compared with control group at $9 \mathrm{~h}$. 
A

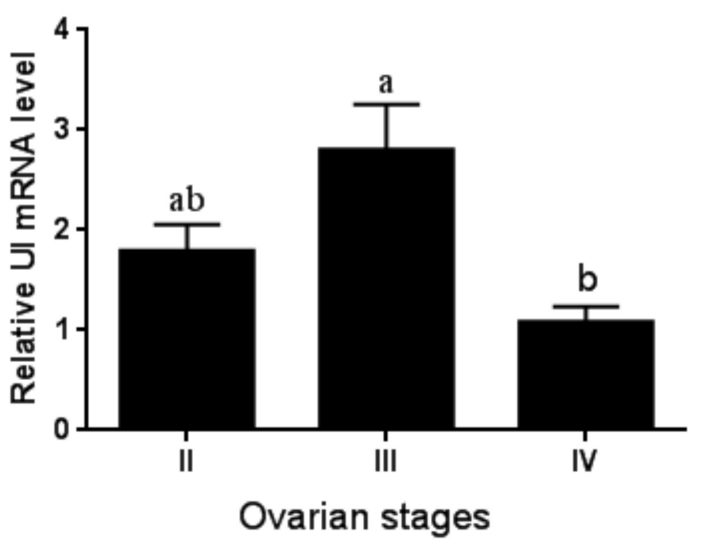

B

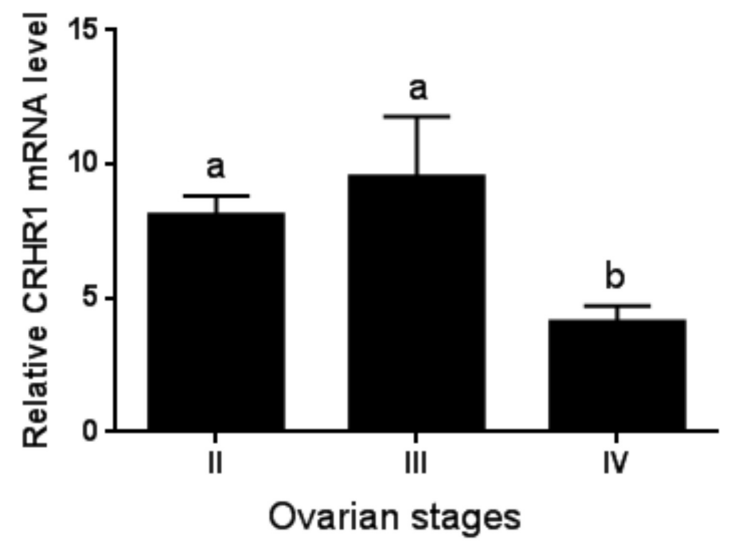

C

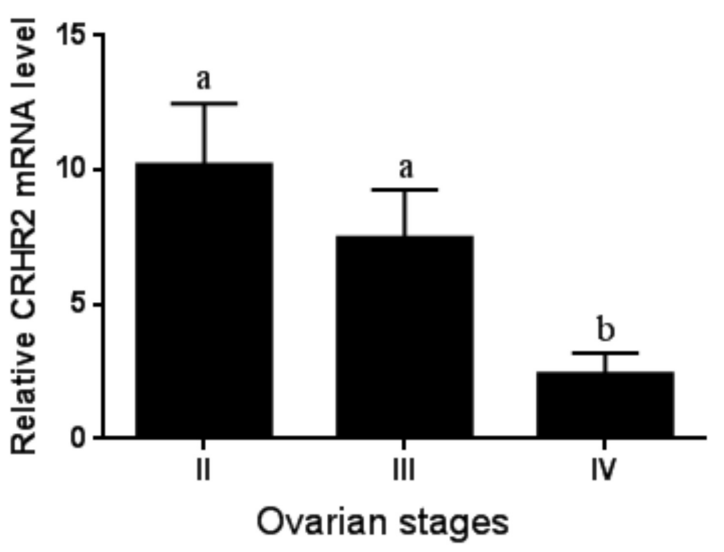

FIGURE 2 | The expression of UI (A), CRHR1 (B), and CRHR2 (C) mRNA at the ovary level during ovarian development. Values are mean $\pm \mathrm{SEM}, n=4$. Means with different letters within a column are significantly different $P<0.05$.

In addition, there was a noteworthy discrepancy between $10 \mathrm{ng} / \mathrm{ml}$ and control group $(P<0.05)$ (Figure 6B). However, after three different concentration of DHP treatment, CRHR2 expression in flounder decreased slightly compared with control group at $9 \mathrm{~h}$ (Figure 6C).

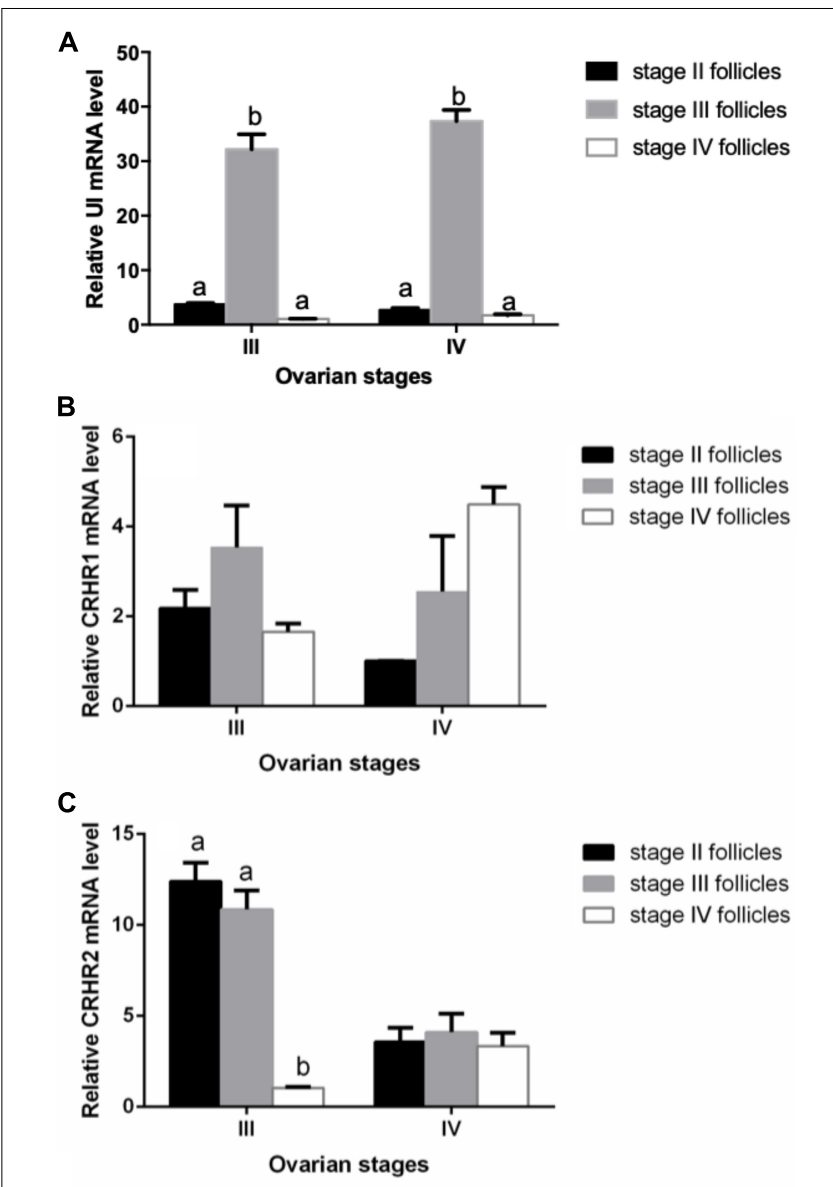

FIGURE 3 | Stage-dependent expression of UI (A), CRHR1 (B), and CRHR2 (C) at the follicles in Japanese flounder. Follicles of the different stages were isolated from Japanese flounder and RNA isolated from each stage for RT-PCR analysis. The expression level was normalized to $\beta$-actin. Each data point represents the mean \pm SEM of three to four replicates. Significant differences among stage of ovarian development are indicated by different letters $(P<0.05)$.

\section{DISCUSSION}

Urotensin I was considered to play an important role in osmotic regulation, vasoconstriction, suppression of orexis, locomotion, cortisol release, and immunes response in teleost (Singh and Rai, 2011). In additional, there are some reports that Ucn I also perform functions in reproduction system in mammals. The levels of Ucn I mRNA in the regressing corpus luteum were significantly higher than that of functioning corpus luteum in normal human ovaries (Muramatsu et al., 2001). The expression of Ucn I gene in granulosa cells reached its maximum in the midluteal phase and decreased in the late luteal phase (Xu et al., 2006, 2007). The dynamic levels of UI, CRHR1 and CRHR2 mRNA were firstly detected in the olive flounder ovary in our study. Interestingly, the mRNA expression of UI, CRHR1, and CRHR2 in the ovary were high at the stage III, but sharply decreased at the stage IV. Meanwhile, UI protein could be detected in the follicular cells and oocytes in stage III and IV follicles of 

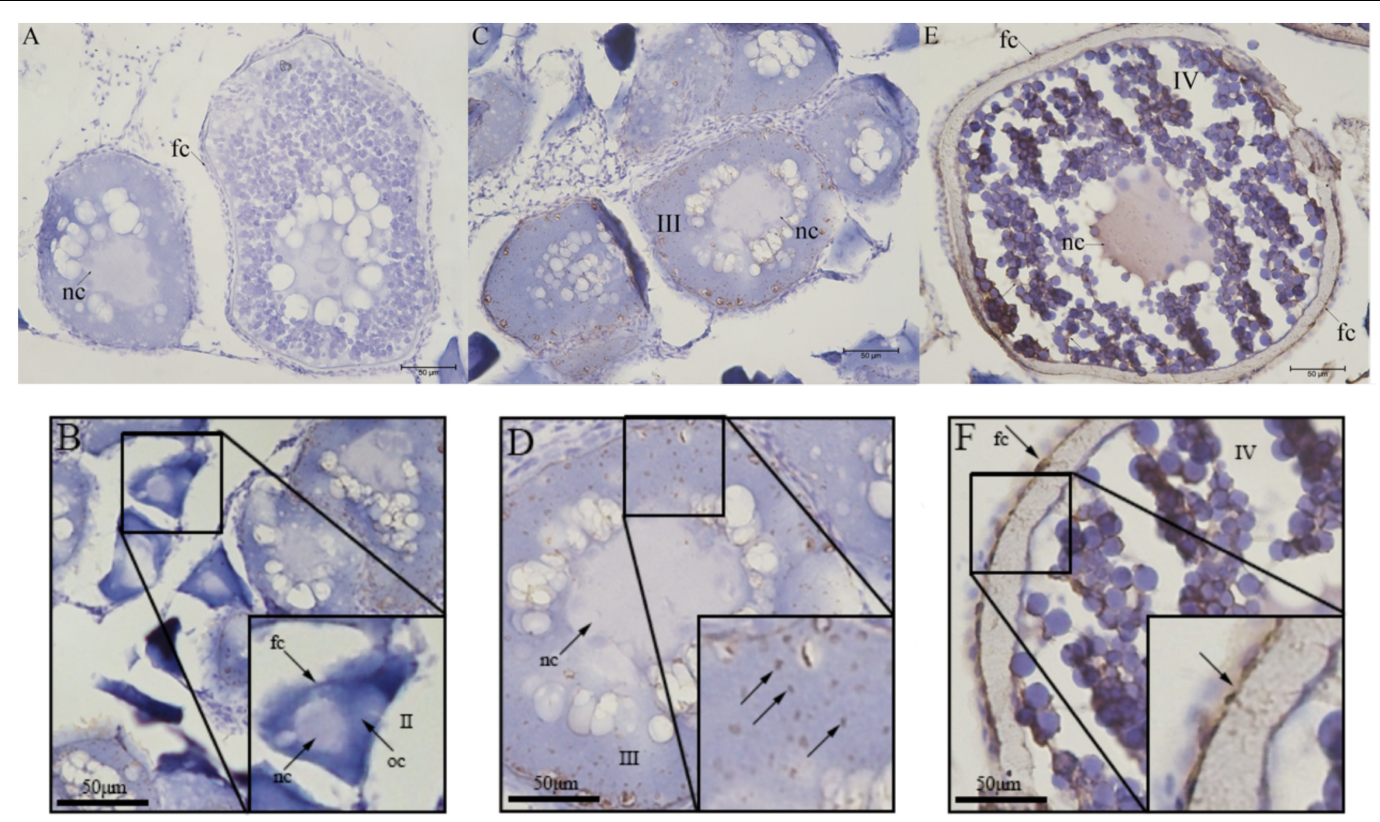

FIGURE 4 | Immunohistochemical localization of UI protein in ovarian tissue of Japanese flounder. The serial sections of the ovaries were immunostained with anti-flounder UI. (A) Negative control, (B) Stage II follicles, (C,D) Stage III follicles, and (E,F) Stage IV follicles. Scale bars: 50 $\mu$ m. Black arrows with/without letters represent specific locations or positive signal, respectively. Stage II 90 300 $\mu \mathrm{m}$, stage III 300 500 $\mu \mathrm{m}$, and stage IV $500 \sim 800 \mu \mathrm{m}$. oc, oocyte; fc, follicular cells; nc, nucleus.

olive flounder. The expression of UI and CRH receptors were regulated by hCG and DHP.

The mRNA expression of urocortin and $\mathrm{CRH}$ receptors was detected in the human and rhesus macaque ovary, and CRH system is involved in the regulation of mammalian reproduction (Xu et al., 2006; Zoumakis et al., 2009; Makrigiannakis et al., 2018). High sequence similarity between mammal and teleost suggested a conserved evolutionary role among CRH-like peptide in vertebrates. Our previous study has demonstrated expression levels of mRNA for CRH-related peptides, CRH and UI, shown seasonal changes that reached its lowest expression in April and maximum in August to October in CNSS of euryhaline flounder Platichthys flesus (Lu et al., 2007). The CNSS which is the major contributor for circulating UI was functionally reprogrammed to cope with physiological changes that was used for winter body maintenance and gonadal development ( $\mathrm{Lu}$ et al., 2007). Combined with the current

TABLE 2 | Two-way ANOVA summary on effects of Time (T) and Concentration (C) on the expression of UI mRNA, CRHR1 mRNA, and CRHR2 mRNA.

\begin{tabular}{|c|c|c|c|c|c|c|c|c|c|}
\hline \multirow[b]{3}{*}{ df } & \multicolumn{3}{|c|}{ UI } & \multicolumn{3}{|c|}{ CRHR1 } & \multicolumn{3}{|c|}{ CRHR2 } \\
\hline & T & C & $\mathbf{T}^{*} \mathbf{C}$ & T & C & $\mathbf{T}^{*} \mathbf{C}$ & $\mathbf{T}$ & C & $\mathbf{T}^{*} \mathbf{C}$ \\
\hline & 2 & 3 & 6 & 2 & 3 & 6 & 2 & 3 & 6 \\
\hline MS & 1.503 & 0.973 & 0.501 & 1608.759 & 6.098 & 2.911 & 9.630 & 0.180 & 0.304 \\
\hline $\mathrm{F}$ & 4.375 & 2.831 & 1.458 & 91.022 & 0.345 & 0.165 & 1.488 & 79.669 & 2.511 \\
\hline P & 0.020 & 0.053 & 0.222 & $<0.001$ & 0.793 & 0.985 & $<0.001$ & 0.228 & 0.032 \\
\hline
\end{tabular}

Time, 3, 6, and 9 h; Concentration, 0, 10, 20, and $50 \mathrm{IJ} / \mathrm{ml} \mathrm{hCG}$. study, the dynamic expression of UI mRNA in follicles at different developmental stages of different ovarian developing stages, the ovarian UI, and CNSS UI all contribute to gonadal development.

The CNSS have been well accepted to be the major site where UI were produced, then released by urophysis (Lu et al., 2004). Previous study shown mature breeders of Liza ramada might enhance the synthesis and/or secretion of CRH immunoreactive cells in the nucleus preopticus (NPO) and medulla oblongata (MO) and respond to stress resulting from ovarian maturation and spawning (Mousa and Mousa, 2006). In human ovary, Ucn I with weak immunoreactivity was discovered in thecal internal cells of dominant/non-dominant follicles (including follicles and luteal phase), as well as in granulosa cells of dominant and atresia follicles (Muramatsu et al., 2001). Ucn I could not be detected in rhesus macaque ovaries during the preovulatory phase of corpus luteum (Xu et al., 2006). During the follicular phase, it was reported that $\mathrm{CRH}$, another $\mathrm{CRH}$-related peptide, was found in both theca cells of growing antral $(7-8 \mathrm{~mm}$ in diameter) and the dominant follicles in the human ovary (Muramatsu et al., 2001; Xu et al., 2006). Our study is the first report to provide the detailed localization of UI in the ovary during ovarian development in olive flounder. Immunoreactive UI were detected in the follicular cells and oocyte at the stage III follicle in olive flounder ovary. These results suggested the expression and function of $\mathrm{CRH}$-related peptide maybe stage-specific or species-specific.

On the contrary, in the mid- and late-corpus luteum, immunoreactive Ucn I was discovered in both thecal cells and luteinized granulosa after ovulation (luteal phase). During early 


\section{A}
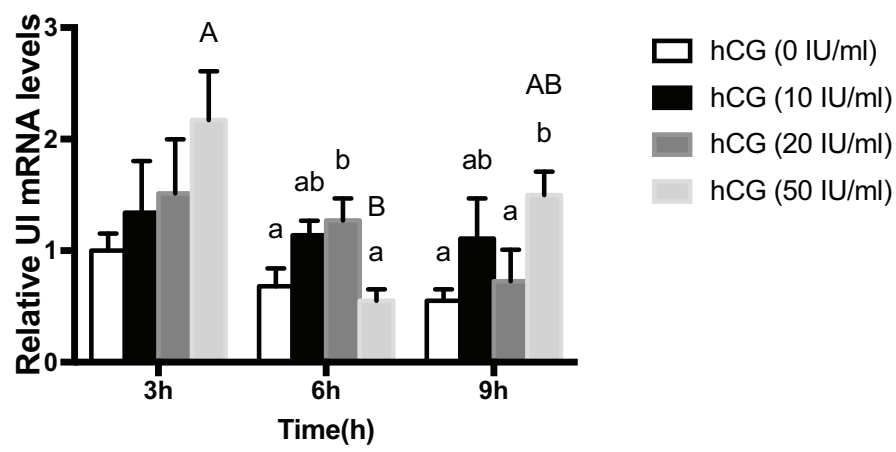

B

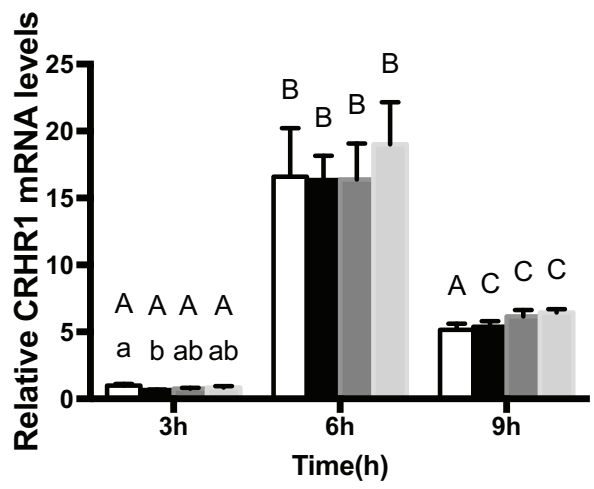

$\square \mathrm{hCG}(0 \mathrm{lU} / \mathrm{ml})$

hCG $(10 \mathrm{IU} / \mathrm{ml})$

hCG $(20 \mathrm{IU} / \mathrm{ml})$

hCG $(50 \mathrm{IU} / \mathrm{ml})$

C

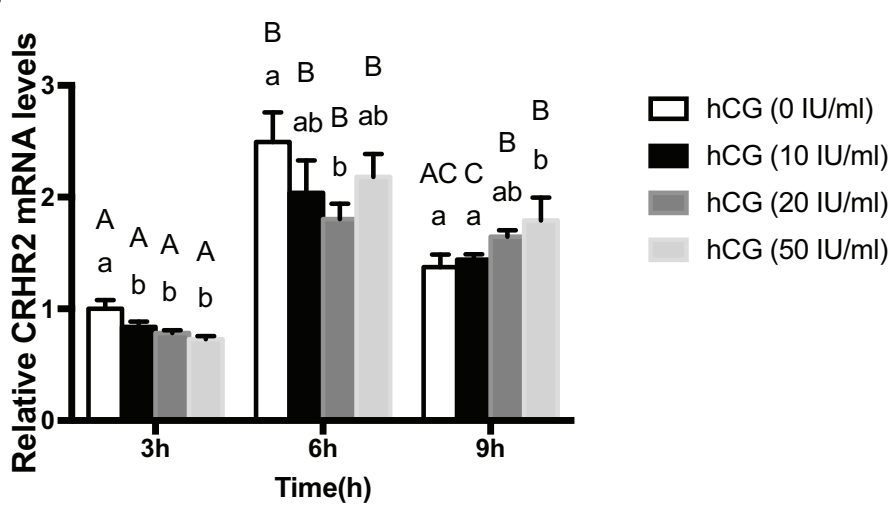

FIGURE 5 | The change of expression level of UI (A), CRHR1 (B), and CRHR2 (C) mRNA in the stage IV follicles regulated by gonadotropin (hCG) in vitro. Data were presented as the fold change relative to $\mathrm{hCG}(0 \mathrm{IU} / \mathrm{ml})$, which was arbitrarily set at 1 . Values are means $\pm \mathrm{SEM}, n=6$ per group. Different lowercase indicates statistical significance $(P<0.05)$ in concentration-dependent manner and different capital indicate statistical significance in time-dependent manner $(P<0.05)$.

corpus luteal degeneration, luteinized thecal cells, but not in luteinized granulosa cells and the Corpus albicans, showed strong Ucn I immunoreactivity. Ultimately, the immunoreactivity of luteinized granulosa and thecal cells to Ucn I was weak in the corpus luteum from pregnant females (Muramatsu et al., 2001; Florio et al., 2004). Therefore, Ucn I have been presumed to be synthesized locally from steroidogenic luteal cells and to function in autocrine and/or paracrine ways (Wypior et al., 2011). Our immunohistochemistry results indicated that UI proteins were associated with the follicular cells and oocytes during the ovarian development. In stage II follicle, immunoreactive UI was not detected in both follicular cells and oocyte. However, in the stage III and stage IV, a strong signal of immunoreactivity for UI has been detected, suggested that processed causing or associated with postvitellogenic follicles. It implied that UI may not be involved in previtellogenesis but in the postvitellogenesis during the ovarian development of flounder. A recent study in Japanese eel Anguilla japonica has shown that GnRH neurons and CRH neurons exist reciprocal connections in the brain (Amano et al., 2014). Whether ovarian UI has been involved in teleost oocyte 
A

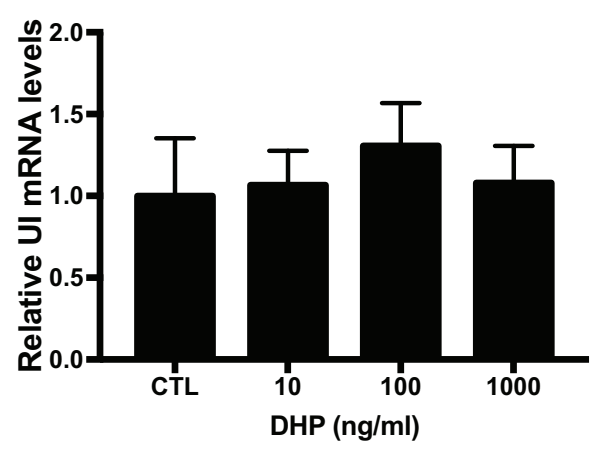

B

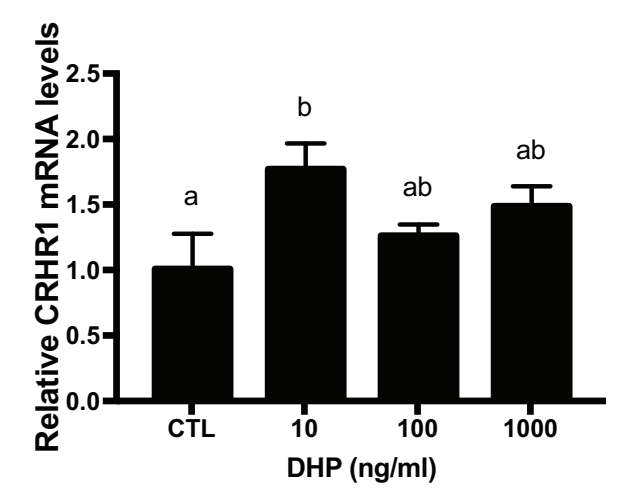

C

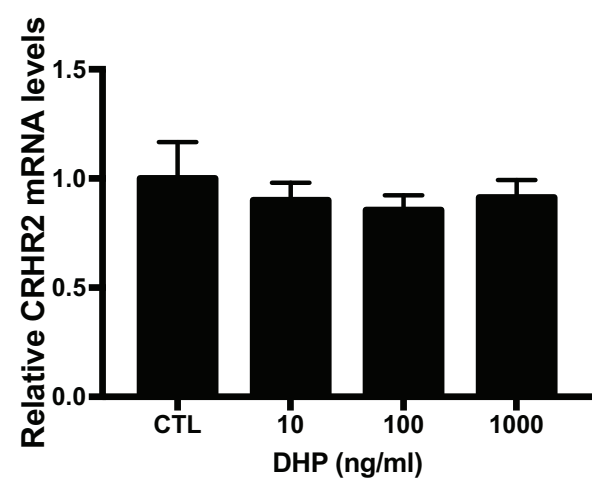

FIGURE 6 | mRNA expression for UI (A), CRHR1 (B), and CRHR2 (C) mRNA in the stage IV follicles induced by DHP for $9 \mathrm{~h}$ in vitro. Data were presented as the fold change relative to control group, which was arbitrarily set at 1 . Values are means \pm SEM, $n=6$ per group. Means with different letters within a column are significantly different $P<0.05$.

maturation and/or ovulation will be an interesting problem to be solved in the future.

Although some researches have shown the expression and secretion of $\mathrm{CRH}$-related peptides might regulated by hormones, but the details of the regulatory mechanisms of UI secretion from peripheral tissues were unknown. Gonadotropin and DHP were known to play major roles in ovarian development and oocyte maturation in teleost. In common carp Cyprinus carpio, the DHP content in the plasma elevated significantly in specimens with migrating oocytes compared to other stages (Aizen et al., 2012;
Vazirzadeh et al., 2014). In greater amberjack Seriola dumerili, the concentration of plasma LH slowly elevated from cortical alveolus and kept high level in middle vitellogenesis and atresia (Nyuji et al., 2016). Studies have shown that hCG induces the maturation of oocyte by interacting with fish receptors of LH in a similar manner to fish luteinizing hormone (LH) (Tan et al., 2009). CRH immunoreactive cells in the NPO and MO dramatically increased their secretory activity during spawning induced by hCG (Mousa and Mousa, 2006). In primates, gonadotropin has no effect on the expression of CRH receptors (Xu et al., 2006). The expression of Ucn I has no obvious difference when treated with the antagonists or agonists of gonadotropin-releasing hormone (Sanchez et al., 2010; Celik et al., 2013). In the current study, the gonadotropin altered UI and $\mathrm{CRH}$ receptors expression in isolated ovarian follicles in time-dependence manner. Although there was no remarkable change in the mRNA expression of UI and CRHR2 after $9 \mathrm{~h}$ of incubation with DHP, however, DHP could induce expression changes of CRHR1. Together, these studies indicated that hCG or DHP were involved in the regulation of UI and CRH receptors expression in the ovary of the olive flounder. Studies on the effects of UI and $\mathrm{CRH}$ receptors on reproduction are rare in teleost, so further studies are needed to elucidate how $\mathrm{CRH}$-related peptides regulate the reproduction of olive flounder.

\section{CONCLUSION}

To sum up, our research provided the first particular analysis of the UI and CRH receptors expression in teleost during ovarian development. The profile of UI and CRHR mRNA expression and localization of UI in the ovary and follicle level suggested that UI might involve in postvitellogensis during ovarian development in teleost. Furthermore, the expression of UI and $\mathrm{CRH}$ receptors in the follicle might regulated by the hCG or DHP. These results indicated that UI and CRH receptors may play an important role in olive flounder ovarian development.

\section{DATA AVAILABILITY}

All datasets generated for this study are included in the manuscript and/or the supplementary files.

\section{ETHICS STATEMENT}

The experimental program was approved by the Animal Ethics Committee of Shanghai Ocean University (Shanghai, China) and complied with the Guidelines on Ethical Treatment of Experimental Animals set by the Ministry of Science and Technology, China.

\section{AUTHOR CONTRIBUTIONS}

$\mathrm{HZ}, \mathrm{AC}$, and WL designed the experiments and wrote the manuscript. $\mathrm{HZ}$ and $\mathrm{CG}$ carried out the experiments. $\mathrm{HZ}$ analyzed the experimental results. 


\section{FUNDING}

We gratefully acknowledge the National Natural Science Foundation of China (31572599 and 41376134), Innovation

\section{REFERENCES}

Aizen, J., Kobayashi, M., Selicharova, I., Sohn, Y. C., Yoshizaki, G., and LevaviSivan, B. (2012). Steroidogenic response of carp ovaries to piscine FSH and LH depends on the reproductive phase. Gen. Comp. Endocrinol. 178, 28-36. doi: 10.1016/j.ygcen.2012.04.002

Amano, M., Mizusawa, N., Okubo, K., Amiya, N., Mizusawa, K., Chiba, H., et al. (2014). Cloning of corticotropin-releasing hormone ( $\mathrm{CRH}$ ) precursor cDNA and immunohistochemical detection of CRH peptide in the brain of the Japanese eel, paying special attention to gonadotropin-releasing hormone. Cell Tissue Res. 356, 243-251. doi: 10.1007/s00441-013-1784-6

Ames, R. S., Sarau, H. M., Chambers, J. K., Willette, R. N., Aiyar, N. V., Romanic, A. M., et al. (1999). Human urotensin-II is a potent vasoconstrictor and agonist for the orphan receptor GPR14. Nature 401, 282-286. doi: 10.1038/45809

Arai, M., Assil, I. Q., and Abou-Samra, A. B. (2001). Characterization of three corticotropin-releasing factor receptors in catfish: a novel third receptor is predominantly expressed in pituitary and urophysis. Endocrinology 142, 446454. doi: 10.1210/en.142.1.446

Bernier, N. J. (2006). The corticotropin-releasing factor system as a mediator of the appetite-suppressing effects of stress in fish. Gen. Comp. Endocrinol. 146, 45-55. doi: 10.1016/j.ygcen.2005.11.016

Bernier, N. J., Lin, X., and Peter, R. E. (1999). Differential expression of corticotropin-releasing factor (CRF) and urotensin I precursor genes, and evidence of CRF gene expression regulated by cortisol in goldfish brain. Gen. Comp. Endocrinol. 116, 461-477. doi: 10.1006/gcen.1999.7386

Bittencourt, J. C., Vaughan, J., Arias, C., Rissman, R. A., Vale, W. W., and Sawchenko, P. E. (1999). Urocortin expression in rat brain: evidence against a pervasive relationship of urocortin-containing projections with targets bearing type 2 CRF receptors. J. Comp. Neurol. 415, 285-312.

Cardoso, J. C., Power, D. M., Elgar, G., and Clark, M. S. (2003). Isolation and characterisation of the corticotropin releasing factor receptor 1 (CRFR1) gene in a teleost fish, Fugu rubripes. DNA Seq. 14, 215-218. doi: 10.1080/ 1042517031000112624

Celik, O., Celik, E., Yilmaz, E., Celik, N., Turkcuoglu, I., Ulas, M., et al. (2013). Effect of ovarian stimulation with recombinant follicle-stimulating hormone, gonadotropin-releasing hormone agonist and antagonists, on follicular fluid stem cell factor and serum urocortin 1 levels on the day of oocyte retrieval. Arch. Gynecol. Obstet. 288, 1417-1422. doi: 10.1007/s00404-0132804-1

Chen, C. C., and Fernald, R. D. (2008). Sequences, expression patterns and regulation of the corticotropin-releasing factor system in a teleost. Gen. Comp. Endocrinol. 157, 148-155. doi: 10.1016/j.ygcen.2008. 04.003

Craig, P. M., Al-Timimi, H., and Bernier, N. J. (2005). Differential increase in forebrain and caudal neurosecretory system corticotropin-releasing factor and urotensin I gene expression associated with seawater transfer in rainbow trout. Endocrinology 146, 3851-3860. doi: 10.1210/en.2005-0004

Ding, Y., He, F., Wen, H., Li, J., Ni, M., Chi, M., et al. (2013). DNA methylation status of cyp17-II gene correlated with its expression pattern and reproductive endocrinology during ovarian development stages of Japanese flounder (Paralichthys olivaceus). Gene 527, 82-88. doi: 10.1016/j.gene.2013. 05.037

Florio, P., Vale, W., and Petraglia, F. (2004). Urocortins in human reproduction. Peptides 25, 1751-1757. doi: 10.1016/j.peptides.2004.05.026

Fryer, J., Lederis, K., and Rivier, J. (1983). Urotensin I, a CRF-like neuropeptide, stimulates acth release from the teleost pituitary. Endocrinology 113, 2308-2310. doi: 10.1210/endo-113-6-2308

Larsen, D. A., Swanson, P., Dickey, J. T., Rivier, J., and Dickhoff, W. W. (1998). In vitro thyrotropin-releasing activity of corticotropin-releasing hormonefamily peptides in coho salmon, Oncorhynchus kisutch. Gen. Comp. Endocrinol. 109, 276-285. doi: 10.1006/gcen.1997.7031
Program of Shanghai Municipal Education Commission (11YZ151), and the innovation research group developing project in the universities of Shanghai (nutrition, feed, and environment of animal aquaculture).

Lederis, K., Letter, A., Mcmaster, D., Moore, G., and Schlesinger, D. (1982) Complete amino acid sequence of urotensin I, a hypotensive and corticotropinreleasing neuropeptide from Catostomus. Science 218, 162-165. doi: 10.1126/ science.6981844

Liu, Y. X., Wang, G. X., Liu, Y., Hou, J. L., Wang, Y. F., Si, F., et al. (2012). Genetic verification of doubled haploid Japanese flounder, Paralichthys olivaceus by genotyping telomeric microsatellite loci. Aquaculture 324, 60-63. doi: 10.1016/ j.aquaculture.2011.10.044

Livak, K. J., and Schmittgen, T. D. (2001). Analysis of relative gene expression data using real-time quantitative PCR and the 2(-Delta Delta C(T)) Method. Methods 25, 402-408. doi: 10.1006/meth.2001.1262

Lovejoy, D. A. (2009). Structural evolution of urotensin-I: reflections of life before corticotropin releasing factor. Gen. Comp. Endocrinol. 164, 15-19. doi: 10.1016/ j.ygcen.2009.04.014

Lovejoy, D. A., and Balment, R. J. (1999). Evolution and physiology of the corticotropin-releasing factor (CRF) family of neuropeptides in vertebrates. Gen. Comp. Endocrinol. 115, 1-22. doi: 10.1006/gcen.1999.7298

Lu, W., Dow, L., Gumusgoz, S., Brierley, M. J., Warne, J. M., Mccrohan, C. R., et al. (2004). Coexpression of corticotropin-releasing hormone and urotensin I precursor genes in the caudal neurosecretory system of the euryhaline flounder (Platichthys flesus): a possible shared role in peripheral regulation. Endocrinology 145, 5786-5797. doi: 10.1210/en.2004-0144

Lu, W., Worthington, J., Riccardi, D., Balment, R. J., and Mccrohan, C. R. (2007). Seasonal changes in peptide, receptor and ion channel mRNA expression in the caudal neurosecretory system of the European flounder (Platichthys flesus). Gen. Comp. Endocrinol. 153, 262-272. doi: 10.1016/j.ygcen.2007. 05.004

Makrigiannakis, A., Vrekoussis, T., Zoumakis, E., Navrozoglou, I., and Kalantaridou, S. N. (2018). CRH receptors in human reproduction. Curr. Mol. Pharmacol. 11, 81-87. doi: 10.2174/1874467210666170224094146

Morley, S. D., Schonrock, C., Richter, D., Okawara, Y., and Lederis, K. (1991). Corticotropin-releasing factor (CRF) gene family in the brain of the teleost fish Catostomus commersoni (white sucker): molecular analysis predicts distinct precursors for two CRFs and one urotensin I peptide. Mol. Mar. Biol. Biotechnol. 1, 48-57. doi: 10.1007/s10409-009-0282-2

Mousa, S. A., and Mousa, M. A. (2006). Involvement of corticotropin-releasing factor and adrenocorticotropic hormone in the ovarian maturation, seawater acclimation, and induced spawning of Liza ramada. Gen. Comp. Endocrinol. 146, 167-179. doi: 10.1016/j.ygcen.2005.10.002

Muramatsu, Y., Sugino, N., Suzuki, T., Totsune, K., Takahashi, K., Tashiro, A., et al. (2001). Urocortin and corticotropin-releasing factor receptor expression in normal cycling human ovaries. J. Clin. Endocrinol. Metab. 86, 1362-1369. doi: $10.1210 /$ jcem.86.3.7299

Nyuji, M., Kazeto, Y., Izumida, D., Tani, K., Suzuki, H., Hamada, K., et al. (2016). Greater amberjack Fsh, Lh, and their receptors: plasma and mRNA profiles during ovarian development. Gen. Comp. Endocrinol. 225, 224-234. doi: 10. 1016/j.ygcen.2015.10.008

Oki, Y., and Sasano, H. (2004). Localization and physiological roles of urocortin. Peptides 25, 1745-1749. doi: 10.1016/j.peptides.2004.06.023

Pittman, Q. J., and Hollenberg, M. D. (2009). Urotensin I-CRF-Urocortins: a mermaid's tail. Gen. Comp. Endocrinol. 164, 7-14. doi: 10.1016/j.ygcen.2009. 04.024

Pohl, S., Darlison, M. G., Clarke, W. C., Lederis, K., and Richter, D. (2001). Cloning and functional pharmacology of two corticotropin-releasing factor receptors from a teleost fish. Eur. J. Pharmacol. 430, 193-202. doi: 10.1016/ S0014-2999(01)01391-7

Radonic, M., and Macchi, G. J. (2009). Gonadal sex differentiation in cultured juvenile flounder, Paralichthys orbignyanus (Valenciennes, 1839). J. World Aquac. Soc. 40, 129-133. doi: 10.1111/j.1749-7345.2008.00229.x

Sanchez, R. L., Reddy, A. P., and Bethea, C. L. (2010). Ovarian steroid regulation of the midbrain corticotropin releasing factor and urocortin systems 
in macaques. Neuroscience 171, 893-909. doi: 10.1016/j.neuroscience.2010. 08.059

Singh, R., and Rai, U. (2011). Immunomodulatory role of urotensins in teleost Channa punctatus. Gen. Comp. Endocrinol. 170, 613-621. doi: 10.1016/j.ygcen. 2010.11.021

Takahashi, K., Totsune, K., Sone, M., Murakami, O., Satoh, F., Arihara, Z., et al. (1998). Regional distribution of urocortin-like immunoreactivity and expression of urocortin mRNA in the human brain. Peptides 19, 643-647. doi: 10.1016/s0196-9781(98)00012-6

Tan, Q., Zagrodny, A., Bernaudo, S., and Peng, C. (2009). Regulation of membrane progestin receptors in the zebrafish ovary by gonadotropin, activin, TGFbeta and BMP-15. Mol. Cell Endocrinol. 312, 72-79. doi: 10.1016/j.mce.2009. 03.011

Vaughan, J., Donaldson, C., Bittencourt, J., Perrin, M. H., Lewis, K., Sutton, S., et al. (1995). Urocortin, a mammalian neuropeptide related to fish urotensin I and to corticotropin-releasing factor. Nature 378, 287-292. doi: 10.1038/378287a0

Vazirzadeh, A., Mojazi Amiri, B., and Fostier, A. (2014). Ovarian development and related changes in steroid hormones in female wild common carp (Cyprinus carpio), from the south-eastern Caspian Sea. J. Anim. Physiol. Anim. Nutr. 98, 1060-1067. doi: 10.1111/jpn.12171

Westring, C. G., Ando, H., Kitahashi, T., Bhandari, R. K., Ueda, H., Urano, A., et al. (2008). Seasonal changes in CRF-I and urotensin I transcript levels in masu salmon: correlation with cortisol secretion during spawning. Gen. Comp. Endocrinol. 155, 126-140. doi: 10.1016/j.ygcen.2007.03.013

Wypior, G., Jeschke, U., Kurpisz, M., and Szekeres-Bartho, J. (2011). Expression of $\mathrm{CRH}, \mathrm{CRH}$-related peptide and $\mathrm{CRH}$ receptor in the ovary and potential
CRH signalling pathways. J. Reprod. Immunol. 90, 67-73. doi: 10.1016/j.jri.2011. 04.009

Xu, J., Hennebold, J. D., and Stouffer, R. L. (2006). Dynamic expression and regulation of the corticotropin-releasing hormone/urocortin-receptorbinding protein system in the primate ovary during the menstrual cycle. J. Clin. Endocrinol. Metab. 91, 1544-1553. doi: 10.1210/jc. 2005-2776

Xu, J., Xu, F., Hennebold, J. D., Molskness, T. A., and Stouffer, R. L. (2007). Expression and role of the corticotropin-releasing hormone/urocortinreceptor-binding protein system in the primate corpus luteum during the menstrual cycle. Endocrinology 148, 5385-5395. doi: 10.1210/en.20070541

Zoumakis, E., Kalantaridou, S. N., and Makrigiannakis, A. (2009). CRH-like peptides in human reproduction. Curr. Med. Chem. 16, 4230-4235. doi: 10. 2174/092986709789578204

Conflict of Interest Statement: The authors declare that the research was conducted in the absence of any commercial or financial relationships that could be construed as a potential conflict of interest.

Copyright (c) 2019 Zhou, Ge, Chen and Lu. This is an open-access article distributed under the terms of the Creative Commons Attribution License (CC BY). The use, distribution or reproduction in other forums is permitted, provided the original author(s) and the copyright owner(s) are credited and that the original publication in this journal is cited, in accordance with accepted academic practice. No use, distribution or reproduction is permitted which does not comply with these terms. 